\title{
A new species of the weevil genus Phyllobius Germar, 1824 (Coleoptera: Curculionidae: Entiminae) from the Pleistocene of northeastern Siberia
}

\author{
S.A. Kuzmina ${ }^{1 *}$, B.A. Korotyaev ${ }^{2}$ \\ ${ }^{1}$ Laboratory of Arthropods, Borissiak Paleontological Institute RAS, Profsoyuznaya St. 123, \\ Moscow, 117868 Russia. \\ ${ }^{2}$ Zoological Institute RAS, Universitetskaya nab. 1, St. Petersburg, 199034 Russia. \\ E-mail:svkuz@yandex.ru, korotyay@rambler.ru \\ * corresponding author
}

ABSTRACT: Weevils of the genus Phyllobius Germar, 1824 (Coleoptera, Curculionidae: Entiminae) are frequent in the Quaternary deposits of northeastern Siberia. A detailed study of the well-preserved Pleistocene fossils (including scales of the vestiture) from the Bolshoy Khomus-Yuryakh River in the Yana-Indigirka lowland (Sakha Republic - Yakutia) results in the recognition of a number of rare weevils including a new species of the genus Phyllobius Germar, 1824 - Ph. (Angarophyllobius) sheri sp.n. which is described in this paper. The new species is closely related to the recent $P h$. kolymensis Korotyaev et Egorov, 1977 currently known from only a few localities in the area of the middle section of the Kolyma River, which had a wider distribution range in the Pleistocene. Phyllobius sheri sp.n. is probably extinct.

How to cite this article: Kuzmina S.A., Korotyaev B.A. 2019. A new species of the weevil genus Phyllobius Germar, 1824 (Coleoptera: Curculionidae: Entiminae) from the Pleistocene of northeastern Siberia // Invert. Zool. Vol.16. No.2. P.154-164. doi: 10.15298/ invertzool.16.2.04

KEY WORDS: Curculionidae, Phyllobius, Angarophyllobius, new species, Pleistocene, Siberia.

\section{Новый вид долгоносиков рода Phyllobius Germar, 1824 (Coleoptera: Curculionidae: Entiminae) из плейстоцена северо-восточной Сибири}

\section{С.А. Кузьмина ${ }^{1 *}$, Б.А. Коротяев ${ }^{2}$}

\footnotetext{
${ }^{1}$ Лаборатория артропод, Палеонтологический институт им. А.А. Борисяка, ул. Профсоюзная 123, Москва, 117868, Россия.

2 Зоологический институт РАН, Университетская наб. 1, Санкт-Петербург, 199034, Россия.

e-mail:svkuz@yandex.ru,korotyay@rambler.ru

* автор для переписки
}

РЕЗЮМЕ: Остатки долгоносиков рода рода Phyllobius Germar, 1824 (Coleoptera, Curculionidae: Entiminae) обильны в четвертичных отложениях северо-восточной 
Сибири. Детальное изучение остатков хорошей сохранности (включая чешуйки наружных покровов) из плейстоценовых отложений с р. Большой Хомус-Юрях на Яно-Индигирской низменности (Республика Саха - Якутия) позволило обнаружить несколько редких видов, в том числе новый вид Phyllobius (Angarophyllobius) sheri sp.n., описание которого приводится в этой статье. Новый вид близок к Ph. kolymensis Korotyaev et Egorov, 1977, найденному ныне только в нескольких местообитаниях в среднем течении Колымы в Магаданской области, но более широко распространенному в плейстоцене. Phyllobius sheri sp.n., по всей вероятности, вымер.

Как цитировать эту статью: Kuzmina S.A., Korotyaev B.A. 2019. A new species of the weevil genus Phyllobius Germar, 1824 (Coleoptera: Curculionidae: Entiminae) from the Pleistocene of northeastern Siberia// Invert. Zool. Vol.16. No.2. P.154-164. doi: 10.15298/ invertzool.16.2.04

КЛЮЧЕВЫЕ СЛОВА: Curculionidae, Phyllobius, Angarophyllobius, новый вид, плейстоцен, Сибирь.

\section{Introduction}

Regular study of Quaternary insects dates from the end of the 19 th century. The problem of extinct species was raised early on and is still under discussion. The famous palaeontologist S. Scudder, who worked on Scarborough Bluff (Ontario, Canada), described 52 species of extinct Pleistocene beetles (Scudder, 1877, 1886, 1890, 1898, 1900). His collection was lost, but subsequent study of these deposits by modern researchers (Morgan, 1972, 1975; Williams et al., 1981) has found no extinct species. Other early researchers (Horn, 1876; £omnicky, 1894; Mjoberg, 1904; Wickham, 1917) also identified Pleistocene insects as extinct species; nevertheless the concept of a mixture of extinct and extant species in the fossil (subfossil) Quaternary material was accepted early on (Wickham, 1919). The subsequent revisions of the £omnicky and Mjoberg collections have shown that all species described by these authors are actually extant (Lindroth, 1960; Coope, 1968a; Angus, 1973).

The modern concept presumes that almost all Pleistocene insects belong to extant species (Elias, 2010) which originated in the Neogene or earlier. The evolutionary stability of insects makes them a perfect tool for palaeoenvironmental reconstructions (Coope, 1959, 1970; Coope et al., 1961; Hopkins et al., 1971; Mat- thews, 1974, 1976). Yet some extinct species are known. First of all there are parasites of the extinct mammals (Grunin, 1973), for example the mammoth botfly Cobboldia russanovi Grunin, 1973. Several extinct species of Donaciinae (Coleoptera: Chrysomelidae) from the Pleistocene of Japan (Hayashi, 1998, 1999a, b) also have been described.

Other evidence of the extinction of Quaternary beetles has been obtained although no descriptions of new species have been published. Kiselev (1981) wrote that at least two fossil beetles from the northeastern Siberia (Carabus cf. hungaricus Fabricius, 1792 and a weevil of the tribe Ptochini) are probably extinct. Some of the Phyllobius remains were reported by him as Ph. (Angarophyllobius) sp. Such identifications often indicate the difficulty of working with the fossil material where a beetle is represented by separated parts of the body, often fragmented. With the weevils, often reliable species identification could be made based on the heads; if only the elytra or a pronotum without head are available, the identification mostly could be possible up to the genus or subgenus level.

New collections provide a mass of material including numerous heads and well-preserved elytra (these fragments of Phyllobius are relatively soft and are damaged easily); some of them retaining even metallic-shining green 


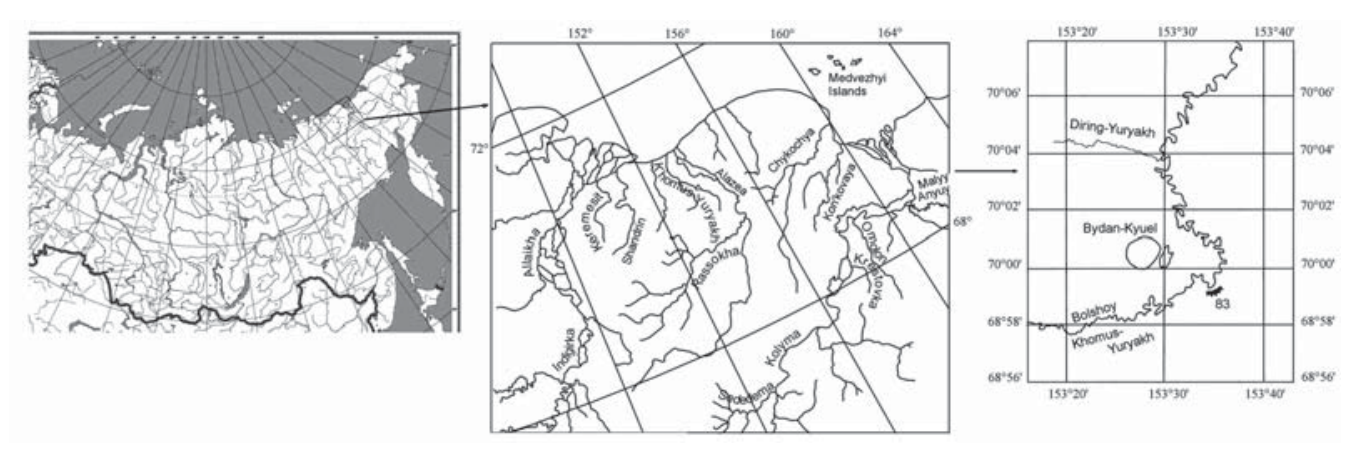

Fig. 1. Map of the location.

Рис. 1. Карта местонахождения.

scales. Here we can see the differences between a number of fossil Phyllobius and their modern relatives. The morphology of the scales (investigated with scanning electron microscope) has played a crucial role in this study aimed at description of a new Pleistocene taxon which is probably extinct now.

\section{Material and Methods}

The main source of the new Pleistocene fossils is the key section 83-Khomus-Yuryakh. The section (Fig. 1) is situated at the Bolshoy Khomus-Yuryakh River $\left(70^{\circ} 00^{\prime} \mathrm{N}, 153^{\circ} 37^{\prime} \mathrm{E}\right)$ in the Yana-Indigirka lowland between the Alazeya and Indigirka rivers (Lozhkin, 1977; Blinov et al., 2009). The section (Fig. 2) was studied by the expedition of the USSR Academy of Sciences with participation of A.V. Sher, A.Ya. Druk, and D.A. Gilichinsky in 1988 and 1989. Insect samples were collected by A.V. Sher (Kuzmina, Elias, 2019). The location was designated as a key section for the regional horizon — Khomus-Yuryakh Bed (Sher, 1997; Virina, 1997) which is situated at the top of Akansky horizon (upper part of the Upper Neopleistocene, about $500 \mathrm{ka} \mathrm{yr}$ ). Later the expedition of 2005 sampled ground ice for chlorine isotope method and got ${ }^{36} \mathrm{Cl} / \mathrm{Cl}$ Age $-496 \pm 78$ ka yr (Blinov et al., 2009) for the KhomusYuryakh Unit. Upper Neopleistocene of the Russian scheme corresponds to the middle Pleistocene (Ionian Stage) of the first draft of the recent international Quaternary scheme (Head et al., 2008). As the discussion of the bound- aries within the Pleistocene is still in progress and the Russian scheme differs from the international one, we can use the Marine Isotope Scale (MIS), and according to this scheme the interval belongs to MIS13 warm stage.

The sample Khomus-Yuryakh-83.25 comes from a sandy-silt unit with lenses of peat and gravel (Fig. 2). The sample 83.25 yields the richest fossil insect assemblage in our record (Kuzmina, 2014, 2015) for northeastern Siberia. The assemblage includes over 10000 fragments of insects, mostly beetles.

The volume of the sample was larger than usual. Despite the visible abundance of insect remains A. Sher has decided to screen extensional sediment body (more than $100 \mathrm{~kg}$ ) trying to get representative assemblage of the rodent teeth for the stratigraphic purposes (Sher, 1997). But Andrei used $0.4 \mathrm{~mm}$ mesh (instead of rodent $1 \mathrm{~mm}$ mesh) having in mind also insect study. The final sample after wet screening and drying in the field weighed about $7 \mathrm{~kg}$ what is much more than usual light $(0.1-0.5 \mathrm{~kg})$ insect sample. The next step was sieving of this concentrate in the laboratory and picking of rodent teeth by unaided eyes and fossil insects with a binocular microscope.

\section{Results}

Species composition of the beetles in Khomus-Yuryakh site

Members of the families Carabidae, Chrysomelidae and Curculionidae dominate the as- 


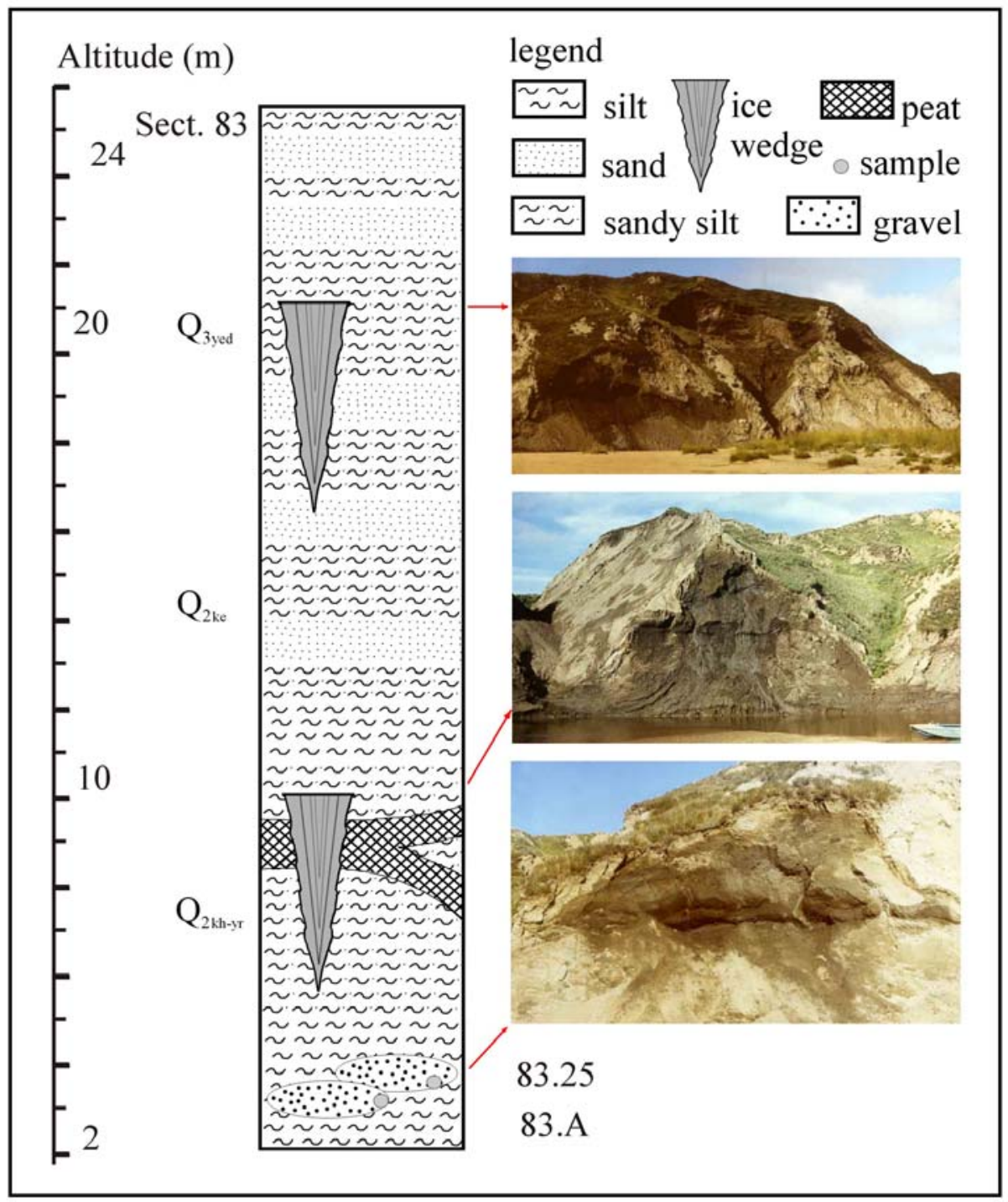

Fig. 2. Scheme of the Khomus-Yuryakh section: $\mathrm{Q}_{2 \mathrm{kh}-\mathrm{yr}}-$ Middle Pleistocene, Khomus-Yuryakh unit; $\mathrm{Q}_{2 \mathrm{ke}}-$ Middle Pleistocene, Keremesit unit; $\mathrm{Q}_{3 \text { yed }}$ - Upper Pleistocene, Yedoma unit. Photo of the section by A.V. Sher.

Рис. 2. Схема разреза Хомус-Юрях: $\mathrm{Q}_{2 \mathrm{kh-yr}}-$ средний плейстоцен, хомус-юряхский горизонт; $\mathrm{Q}_{2 \mathrm{ke}}-$ средний плейстоцен, керемеситский горизонт; $\mathrm{Q}_{\text {зуеd }}$ - верхний плейстоцен, едомный горизонт. Автор фото разреза - А.В. Шер.

semblage, but the most abundant species is the extant pill-beetle, Morychus viridis Kuzmina et Korotyaev, 1987 (Byrrhidae). The last species is very common in the Pleistocene steppe-tundra communities of the Northeast Asia (Berman, 1990).
Weevils constitute almost a half of the assemblage ( $44 \%$ of fragments); they belong to 21 species including several species of Stephanocleonus Motschulsky, 1860, Coniocleonus Motschulsky, 1860, Lepyrus Germar, 1817, Hypera Germar, 1817, Isochnus Thomson, 1859, 
Dorytomus Germar, 1817, Sitona Germar, 1817, Ceutorhynchus Germar, 1824, and Phyllobius spp. These weevils and other beetles (Kuzmina, 2015) indicate mixture of the steppe, tundra, shrub, meadow and wetland habitats. This is a typical pattern of the northeastern Siberian Pleistocene insect faunas (Kiselev, 1981; Kiselev, Nazarov, 2009) representing the extinct steppetundra biome (Sher, 1990).

It is noteworthy that the species diversity of the insect fauna is not high despite the large number of the fossils in the assemblage. The core list of the steppe-tundra insect fauna does not exceed 80-100 species (Kuzmina, 2014) while modern Holocene assemblages from this area are less abundant in number of specimens obtained, but are nevertheless more diverse (Kuzmina, Sher, 2006). Nevertheless, the large volume of sample 83.25 provides a slightly longer species list than usual including several problematic identifications for Lepyrus, Ceutorhynchus, Phyllobius, and in addition to weevils also for Chrysolina Motschulsky, 1860 (Chrysomelidae) and Aphodius Illiger, 1798 (Scarabaeidae).

A thorough investigation of 1460 fragments of Phyllobius from the sample Khomus-Yuryakh83.25 allowed recognition of the following species: 1 - Ph. virideaeris Laicharting, 1781 (about 7\%); $2-P h$. kolymensis Korotyaev et Egorov, 1977 (about 80\%); $3-P h$. sheri sp.n. (about 10\%), and 4 - Phyllobius sp. 2 (about 3\%). Ph. sheri sp.n. is described below.

\section{Description of the new species}

Family Curculionidae Latreille, 1802

Subfamily Entiminae Schoenherr, 1826

Genus Phyllobius Germar, 1824

Subgenus Angarophyllobius Korotyaev et Egorov, 1977

Phyllobius (Angarophyllobius) sheri Kuzmina et Korotyaev sp.n.

Figs. 3C, 4A, B, D.

Type material. Holotype: female head, pronotum and fused elytra with abdomen glued on a plate. Label data: Northern Yakutia, Bolshoy Khomus-Yuryakh River, Q2, A. Sher, 1988.
Paratypes (all labelled as above): head with deciduous process on right mandible; head with deciduous processes on both mandibles; head with deciduous process on right mandible; pronotum; left female elytron; right less convex (probably male) elytron. All type material is deposited in the collection of the Zoological Institute, Russian Academy of Sciences, St. Petersburg.

Description. Body black; head, pronotum and elytra moderately densely clothed with slightly lustrous light green or, rarely, grey rather large round, wide tear-shaped or oval scales with length less than 1.5 widths.

Rostrum considerably narrower than head capsule, weakly transverse in male and broader in female (1.5 times as broad as long); in male weakly, in female moderately narrowing from base toward mid-length, weakly roundly broadened apically. Rostral dorsum forming distinct angle with frons, rather strongly depressed along midline; lateral margins of dorsum moderately convex, parallel in middle part of length and moderately widely roundly diverging apically. Rostral dorsum weakly convex longitudinally, weakly and gently bevelled apically, with well developed epistome rather far producing acuteangularly posteriorly into the depressed part of dorsal surface. Frons flattened; its width triple as great as longitudinal diameter of eye. Head capsule behind eyes not swollen, almost parallel-sided. Punctation of rostrum and head capsule formed by moderately large but rather deep, moderately dense punctures, not rugose; intervals between punctures mostly (occasionally everywhere) shiny. Eyes small, rather strongly convex, almost round. Antennae not preserved. Some heads retain one (Fig. 3A) or two mandibular appendages.

Pronotum more than 1.4 times as broad as long, broadest at middle or slightly distal to it, with sides moderately rounded, with well developed basal and apical constrictions; base weakly rounded, occasionally shallowly sinuous medially; apical margin shallowly sinuous medially. Pronotal disc slightly convex or flat. Punctation shallow, relatively fine, dense, not rugose; intervals between punctures mostly shiny, especially on sides. Median line some- 


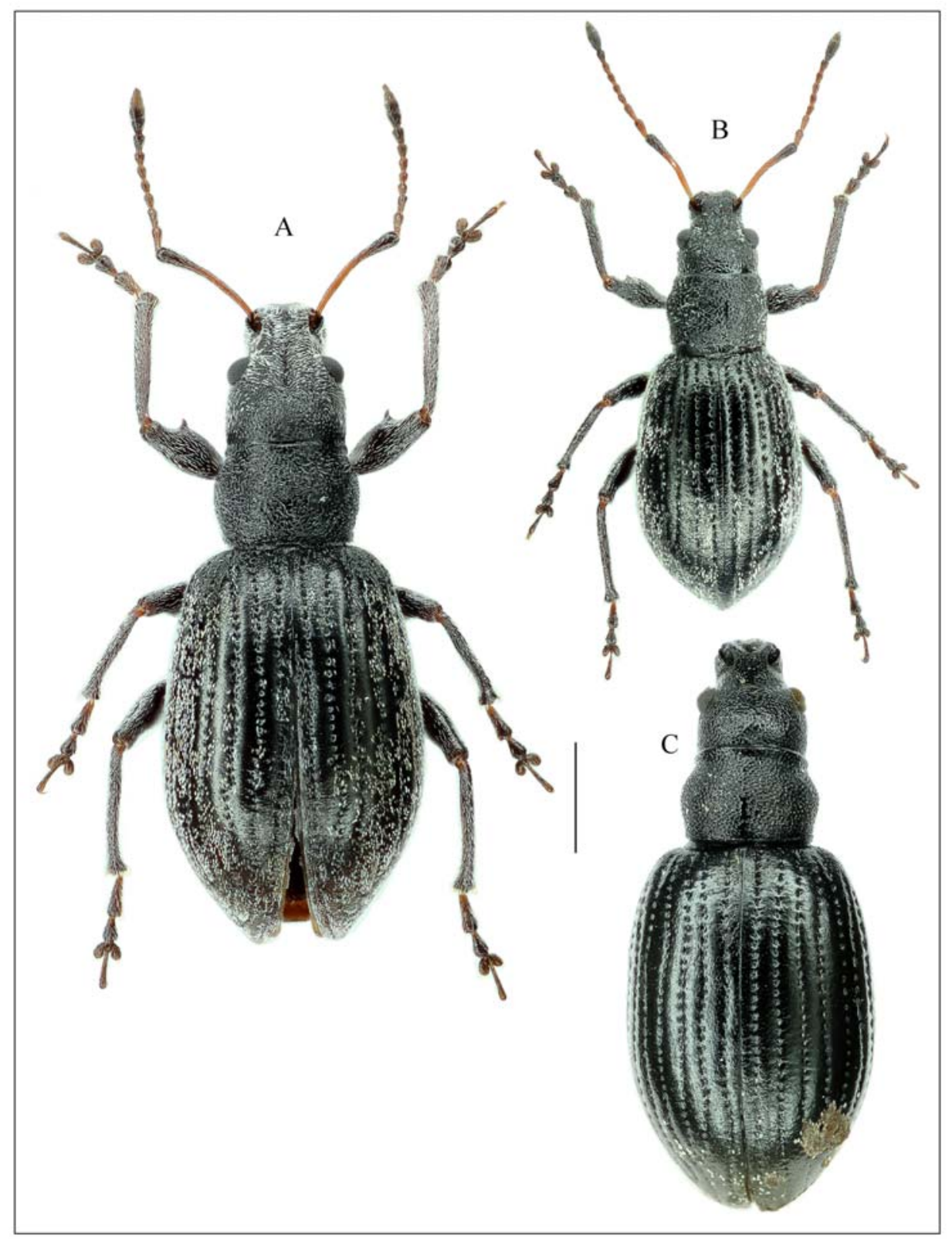

Fig. 3. Phyllobius (Angarophyllobius), females, habitus. A-Ph. kolymensis Korotyaev et Egorov; $B-P h$. virens (Faust); $C-P h$. sheri sp.n.

Рис. 3. Phyllobius (Angarophyllobius), самки, общий вид. A-Ph. kolymensis Korotyaev et Egorov; $B-$ Ph. virens (Faust); $C-P h$. sheri sp.n.

times slightly elevated in middle part of its length or in basal part.

Scutellum small, triangular, in the holotype somewhat raised above elytral surface.
Elytra rather broad and convex, their length/ width ratio in two well preserved females (with fused elytra and basal abdominal sternites) 1.46 and 1.50. Humeral tubercles present but strongly 

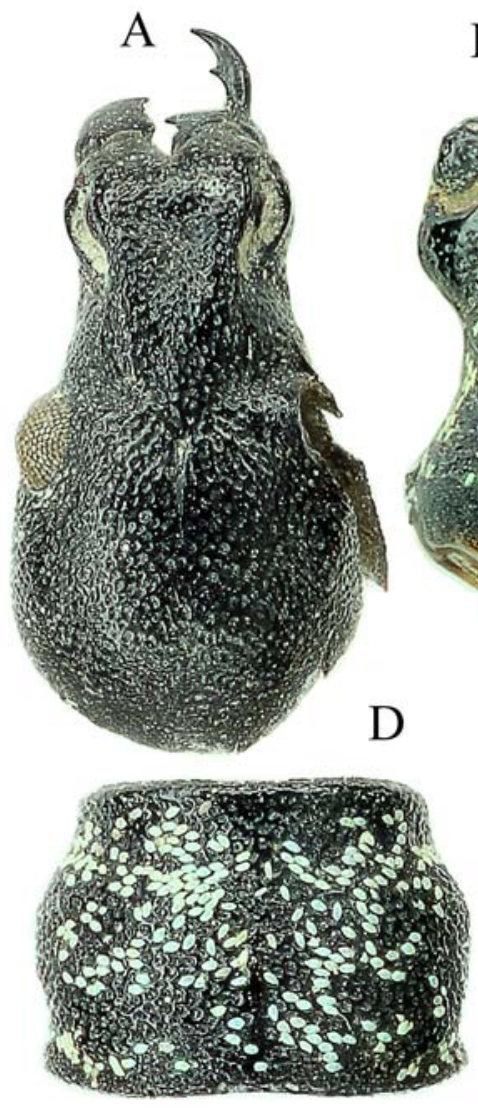

B

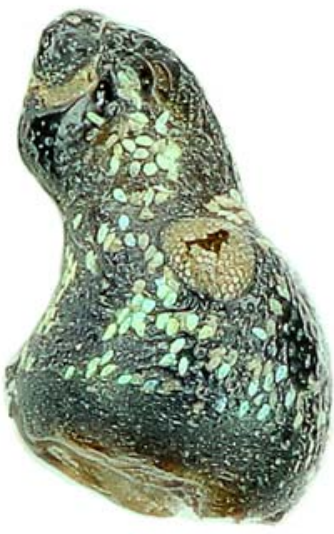

C

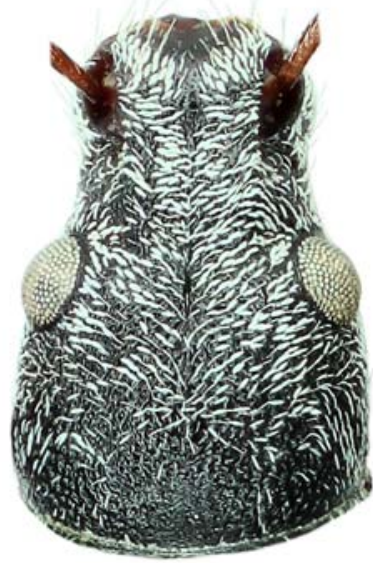

$\mathrm{E}$

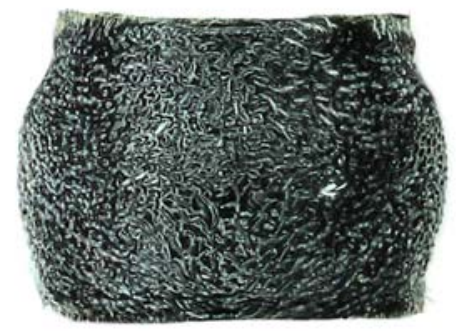

Fig. 4. Phyllobius (Angarophyllobius) sheri sp.n. and Ph. (Angarophyllobius) kolymensis Korotyaev et Egorov, head dorsally (A, C) and laterally (B), and pronotum dorsally (D, E). A, B, D - Ph. sheri sp.n.; C, E - Ph. kolymensis Korotyaev et Egorov.

Рис. 4. Phyllobius (Angarophyllobius) sheri sp.n. и Ph. (Angarophyllobius) kolymensis Korotyaev et Egorov, голова сверху (А, С) и сбоку (В) и переднеспинка сверху (D, Е). A, В, D - Ph. sheri sp.n.; C, $\mathrm{E}-$ Ph. kolymensis Korotyaev et Egorov.

rounded. Basal margin of elytra near scutellum almost uniformly smoothened, becoming steeper toward shoulders. Apices of elytra always narrowly rounded. Elytral striae deep and wide; interstriae much broader than striae, slightly or moderately convex, usually moderately shiny.

Legs not preserved.

Distance between middle and hind coxal cavities equal to longitudinal diameter of middle coxal cavities.

Length of pronotum $0.97-1.0$, width 1.38$1.40 \mathrm{~mm}$; length of elytron $3.5-4.0 \mathrm{~mm}$.

Male known from several separated elytra.
Differential diagnosis. The new species is probably most closely related to $P$ h. kolymensis Korotyaev et Egorov, 1977 (Korotyaev, Egorov, 1977). These two species are very similar in the structure of the head and in the proportions and shape of pronotum; the elytra are also quite similar: in both species they are convex, with rounded shoulders and sides, and also with rounded (probably in $P h$. sheri sp.n. as well as $P h$. kolymensis) and slightly divergent apices.

Phyllobius sheri sp.n. differs from Ph. kolymensis in the larger and wider green scales, sharper angle between the frons and rostral 

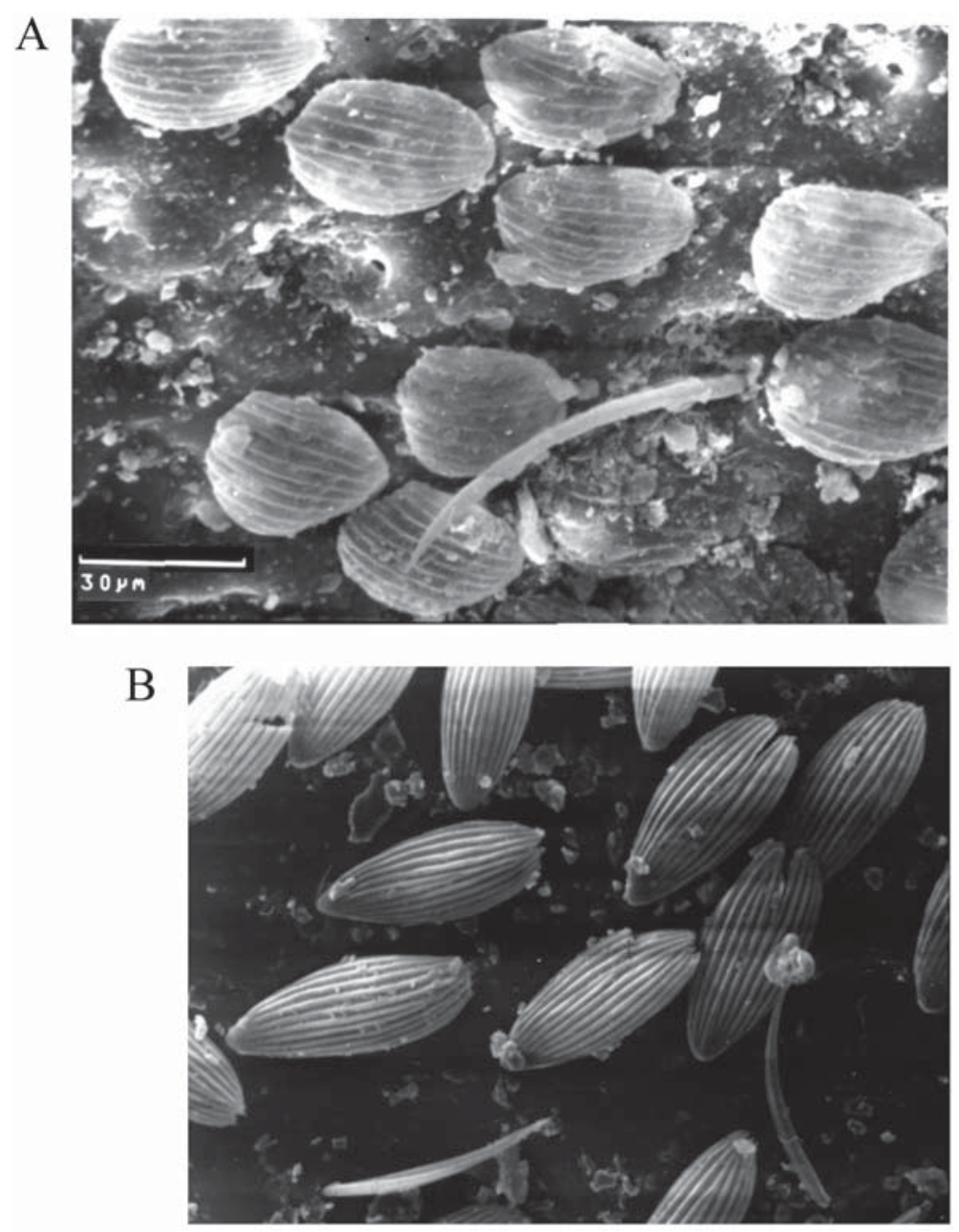

Fig. 5. Phyllobius (Angarophyllobius), scales. A - Ph. kolymensis Korotyaev et Egorov; B — Ph. sheri sp.n. Рис. 5. Phyllobius (Angarophyllobius), чешуйки. А - Ph. kolymensis Korotyaev et Egorov; B - Ph. sheri sp.n.

dorsum, more elevated lateral margins of the rostrum, and more strongly convex epistome.

Taxonomic notes. Taking into account the close similarity of Phyllobius sheri sp.n. to Ph. kolymensis, we can assume that the femora of the fossil species also had a well-developed tooth, and the anal sternite of male was moderately to deeply depressed. The aedeagus of Angarophyllobius species is strongly sclerotized and may occur in the samples containing the remnants of members of this subgenus. The aedeagus of $P h$. kolymensis has uniformly sclerotized ventral surface with two large oval mem- branous areas at the apex separated by a sclerotized area; the median apical process is rather broad. These features allow differentiation $P h$. kolymensis from the closely allied Ph. fumigatus Boheman, 1843 which is widespread in East Siberia and in the south of the Russian Far East. The aedeagus of Ph. fumigatus has smaller apical membranous areas connected by a membrane; the apical process is half as broad as in Ph. kolymensis (Korotyaev, Egorov, 1977: p. 445, figs. 159-161 and 156-158).

Distribution. Northeastern Siberia: Kolyma Lowland, Pleistocene. 
Etymology. The species is named after the famous palaeontologist Andrei Vladimirovich Sher who collected the sample.

\section{Discussion}

Phyllobius Germar, 1824 is a Palaearctic genus of the broad-nosed weevils (family Curculionidae, subfamily Entiminae) with 154 species (Alonso-Zarazaga et al., 2017). Most of the Phyllobius species are associated with trees and shrubs. This is true also for the subgenus Angarophyllobius Korotyaev et Egorov, 1977 (Korotyaev, Egorov, 1977; Korotyaev, 1984), with the only exception of the Mongolian Ph. grubovi Korotyaev,1984 which has been found by I.M. Kerzhner on Oxytropis oligantha Bge. in the alpine steppe at an elevation of $3000 \mathrm{~m}$ (Korotyaev, 1984). Single specimens of Phyllobius kolymensis (Figs 3-5) were found on herbs in the steppe community, and the species was abundant in the mesophytic meadows in the Kolyma River floodplain (Berman et al., 2001). The first two specimens were taken by B.K. from Spiraea sp. bushes in the Kolyma flood plain (Korotyaev, Egorov, 1977).

The subgenus Angarophyllobius includes 21 species in the East Siberia, the Russian Far East, and Mongolia; in addition Ph. sauricus Korotyaev et Egorov, 1977, is known from Eastern Kazakhstan (Saur Range), and Ph.przewalskii Korotyaev, 1979, from Northern China. In the modern insect fauna of Yakutia the subgenus is represented by four species: Ph. fumigatus Boheman, 1843, Ph. hochhuthi Faust, 1883, Ph. femoralis Boheman, 1842, and Ph. virens (Faust, 1890). The first two species have prominent shoulders and well-developed wings (the fossil weevils have rounded shoulders); $P h$. femoralis is smaller and has no broad scales on the dorsal surface; and $P h$. virens has rounded shoulders but it is much smaller than the fossil specimens.

Phyllobius sheri sp.n. is known, in addition to the type locality, probably from other sites. Our database of Quaternary fossil insects (Sher et al., 2006) shows that Phyllobius sp. has been recorded in 8 samples of 7 sites; Phyllobius
(Angarophyllobius) sp. in four samples from three sites, but $\mathrm{Ph}$. kolymensis is much more common: 184 samples from 29 sites. Why the new species has been recorded from one site only? The reason probably is that Phyllobius remains are common in the Late Pleistocene sites while $P h$. sheri should be associated with older assemblages. Ph. kolymensis is presented in some Middle or Early Pleistocene samples such as Krestovka, Chukochya and Keremesit but the number of fossils is small, usually 1-2 specimens per sample. Another problem is that preservation of Phyllobius is not always good, elytra are often deformed and crumpled, scales are rarely preserved. We expect the findings of Ph. sheri: 1 - in the Early-Middle Pleistocene deposit; 2 - in large assemblages; 3 - in steppe-tundra assemblages; 4 - the preservation of the fossils is good. Right now there is the only one sample which satisfies these requirements - 83.25 from Bolshoy Khomus-Yuryakh River.

\section{Conclusion}

The description of the Phyllobius (Angarophyllobius) sheri sp.n demonstrates the existence of extinct beetle species in the Pleistocene steppe-tundra community at least before the Late Pleistocene. The extant species Ph. (Angarophyllobius) kolymensis (which is the closest relative of Ph. sheri sp.n.) has narrowed down its distribution dramatically since the late Pleistocene and is recently found only in a restricted area in the upper reach of the Kolyma River where it occupies relict steppe patches.

The new species is known from the type locality and floodland habitats only - the Middle Pleistocene of the Bolshoy Khomus-Yuryakh River in the Yana-Indigirka lowland. The description was possible due to excellent preservation of the fossils and extremely large volume of the assemblage. All known other contemporary samples yield only single Phyllobius remains. Most probably the distribution of $P h$. sheri was wider than the type locality; mass collecting of the Early or Middle Pleistocene insects could provide new finds of this species in other areas of the northeastern Siberia. 


\section{Acknowledgements}

We thank G.E. Davidian (All-Russia Research Institute of Plant Protection, St. Petersburg, Russia) for making photos of the weevils, L.T.Protasevich (Paleontological Institute RAS, Moscow) for SEM photos of the scales, and R.B. Angus (c/o Natural History Museum, London, United Kingdom) for advice and linguistic correction of the text. B.K.'s research was made based on the Zoological Institute collection within the state project No. AAAA-A19119020690082-8. We thank Russian Foundation for Basic Research for the financial support (grants 04-04-48770 to S.K. and 19-04-00565 to B.K.).

\section{References}

Alonso-Zarazaga M.A., Barrios H., Borovec R., Bouchard P., Caldara R., Colonnelli E., Gültekin L., Hlavá P., Korotyaev B., Lyal C.H.C., Machado A., Meregalli M., Pierotti H., Ren L., Sánchez-Ruiz M., Sforzi A., Silfverberg H., Skuhrovec J., Trýzna M., Velázquez de Castro A.J., Yunakov N.N. 2017. Cooperative catalogue of Palaearctic Coleoptera Curculionoidea // Monografias Electronicas S.E.A. Vol.8. P.1-729.

Angus R.B. 1973. Pleistocene Helophorus (Coleoptera, Hydrophilidae) from Borislav and Starunia in western Ukraine, with a reinterpretation of M. £omnicki's species, description of a new Siberian species, and comparison with British Weichselian faunas // Philosophical Transactions of the Royal Society. Ser.B. Vol.265. No.869. P.299-326.

Berman D.I. 1990. The phenomenon of mass beetle genus Morychus from Pleistocene deposits in northeastern Asia // Current Research in the Pleistocene. Vol.7. P.101-103.

Berman D.I., Alfimov A.V., Mazhitova G.G., Grishkan I.B., Yurtsev B.A. 2001. [Cold steppes of the NorthEast Asia]. Magadan: IBPN FEB RAS. 183 p. [In Russian]

Blinov A., Alfimov V., Beer J., Gilichinsky D., Schirrmeister L., Kholodov A., Nikolskiy P., Opel T., Tikhomirov D., Wetterich. S. 2009. Ratio of $36 \mathrm{Cl} /$ Clin ground ice of east Siberia and its application for chronometry // Geochemistry, Geophysics, Geosystems. Vol.10. doi:10.1029/2009GC002548.

Coope G.R. 1959. A Late Pleistocene insect fauna from Chelford, Cheshire // Proceedings of the Royal Society. Ser.B. Vol.151. P.70-86.

Coope G.R. 1968. Insect remains from Silts Below Till at Garfield Heights, Ohio // Bulletin of the Geological Society of America. Vol.79. P.753-756.

Coope G.R. 1970. Climatic interpretations of Late Weichselian Coleoptera from the British Isles // Revue de geographie physique et de geologie dynamique. Vol.12. P.149-155.

Coope G.R., Shotton F.W., Strachan I. 1961. A Late Pleistocene fauna and flora from Upton Warren, Worcestershire // Philosophical Transactions of the Royal Society of London. Ser.B. Vol.244. P.379-421. Elias S.A. 2010. Advances in Quaternary Entomology // Developments in Quaternary Sciences. Vol.12. P.1304.

Grunin K.Ya. 1973. [The first find of mammoth stomach botfly Cobboldia (Mamontia, subgen. n.) rusanovi sp.n.(Diptera, Gasterophilidae)]//Entomologicheskoe Obozrenie. Vol.52. No.1. P.228-233 [in Russian].

Hayashi M. 1998. A new species of the genus Donaciella from the Lower Pleistocene in Nagaoka City, Niigata Prefecture, central Japan (Coleoptera: Chrysomelidae: Donaciinae) // Bulletin of the Osaka Museum of Natural History. Vol.52. P.37-47.

Hayashi M. 1999a. A revisional study on fossil Donaciinae from the Plio-Pleistocene Kazusa Group in Saitama Prefecture, Japan, with reference to phylogeny of the extinct Plateumaris dorsata Hayashi (Coleoptera, Chrysomelidae) // Earth Science (Chikyu Kagaku). Vol.53. No.1. P.36-50.

Hayashi M. 1999b. Late Pliocene to Early Pleistocene donaciine fossils from the Uonuma Formation in Higashikubiki hills, Niigata Prefecture, Japan, with description of a new species (Coleoptera: Chrysomelidae, Donaciinae) // Bulletin of the Osaka Museum of Natural History. Vol.53. P.1-22.

Head M.J., Gibbard P.L., Salvador A. 2008. The Quaternary: its character and definition // Episodes. Vol.31. P.234-238.

Hopkins D.M., Matthews J.V., Wolfe J.A., Silberman M.L. 1971. A Pliocene flora and insect fauna from the Bering Strait region // Palaeogeography, Palaeoclimatology, Palaeoecology. Vol.9. P.211-231.

Horn G.H. 1876. Notes on some coleopterous remains from the bone cave at Port Kennedy, Pennsylvania // Transactions of the American Entomological Society. Vol.5. P.241-245.

Kiselev S.V. 1981. [Late Cenozoic Coleoptera of NorthEast Siberia]. Moscow: Nauka. 116 p. [In Russian]

Kiselev S.V., Nazarov V.I. 2009. Late Cenozoic Insects of Northern Eurasia // Paleontological Journal Supplement. Vol.43. No.7. P.723-850.

Korotyaev B.A. 1984. [Contributions to the fauna of the weevil genus Phyllobius Germ. (Coleoptera, Curculionidae) of Mongolia and the USSR] // I.M. Kerzhner (ed.). Nasekomye Mongolii. Leningrad: Nauka Publ. No.9. P.356-365 [in Russian].

Korotyaev B.A., Egorov A.B. 1977. [Review of the weevil genus Phyllobius Germ. (Coleoptera, Curculionidae) of the fauna of Eastern Siberia, Far East of the USSR, and Mongolia, and notes on the species from other regions] // I.M. Kerzhner (ed.). Nasekomye Mongolii. Leningrad: Nauka Publ. No.5. P.379-449.

Kuzmina S. 2014. New approach to the Quaternary studies: QINSIB - the database of Siberian fossil insects // Quaternary International. Vol.341. No.18. P.283-293. 
Kuzmina S.A. 2015. Quaternary insects and environment of the Northeastern Asia // Paleontological Journal. Supplement to Vol.49. No.7. P.1-189.

Kuzmina S.A., Elias S.A., 2019. Andrei V. Sher and his role in Quaternary invertebrate study // Invertebrate Zool. Vol.16. No.2. P.79-88.

Kuzmina S., Sher A. 2006. Some features of the Holocene insect faunas of northeastern Siberia // Quaternary Science Reviews. Vol.25. No.15-16. P.1790-1820.

Lindroth C.H. 1960. Coleopteren - hauptsachlich Carabiden - aus dem Diluvium von Hosbach // Opuscula Entomologica. Vol.25. S.112-128.

Łomnicki A.M. 1894. Pleistocenskie owady z Borislawia (Fauna Pleistocenica insectorum Boryslaviensium) // Wydawnietwa Muzeum imenia Dzieduszyckich. Vol.4. P. 1-116.

Lozhkin A.V. 1977. [Radiocarbon dating of Upper Pleistocene deposits on Novosibirsk Islands and the age of the Yedoma Suite of Northeast USSR] // Doklady AN SSSR. Vol.235. No.2. P.435-437 [in Russian].

Matthews J.V. 1974. Quaternary environments at Cape Deceit (Seward Peninsula, Alaska): evolution of tundra ecosystem // Geological Society of America Bulletin. Vol.85. P.1353-1384.

Matthews J.V. 1976. Evolution of the subgenus Cyphelophorus (genus Helophorus, Hydrophilidae, Coleoptera): description of two new species and discussion of Helophorus tuberculatus Gyll. // Canadian Journal of Zoology. Vol.54. No.5. P.652-673.

Mjoberg E. 1904. Über eine schwedische interglaciale Coleopteren-Species // Geologiska Foreningens i Stockholm Forhandlingar. Bd.26. S.493-497.

Morgan A. 1972. The fossil occurrence of Helophorus arcticus Brown (Coleoptera Hydrophilidae) in Pleistocene deposits of the Scarborough Bluffs, Ontario // Canadian Journal of Zoology. Vol.50. P.555-558.

Morgan A. 1975. Fossil beetle assemblages from the Early Wisconsinan Scarborough Formation // Quaternary Non-Marine Paleoecology Conference. Abstracts. University of Waterloo. P.15.

Scudder S.H. 1877. Description of two species of Carabidae found in the Interglacial deposits of Scarboro Hts., in Toronto, Canada // United States Geological Survey of the Territories (Hayden). Vol.B3. P.763764.
Scudder S.H. 1886. The operations of a prehistoric beetle // Canadian Entomologist. Vol.18. P.194-196.

Scudder S.H. 1890.The fossil insects of North America // United States Geological Survey Report. Vol.8. P. 1734.

Scudder S.H. 1898. The Pleistocene beetles of Fort River, Massachusetts // Monographs of the United States Geological Survey. Vol.24. P.740-746.

Scudder S.H. 1900. Canadian Fossil Insects, 4. Additions to the coleopterous fauna of the interglacial clays of the Toronto district // Geological Survey of Canada, Contributions to Canadian Palaeontology. Vol.2. P.67-92.

Sher A.V. 1997. A brief overview of the Late-Cenozoic history of the Western Beringian lowlands. // M.E. Edwards, A.V. Sher, R.D. Guthrie (eds). Terrestrial paleoenvironmental studies in Beringia. Fairbanks: University of Alaska Museum. P.3-6.

Sher A.V. 1990. [Actualism and disconformism in the studies on the ecology of Pleistocene mammals] // Zhurnal obschei biologii. Vol.51. No.2. P.163-177 [in Russian].

Sher A.V., Kuzmina S.A., Kiselev S.V., Korotyaev B.A., Alfimov A.V., Berman D.I. 2006. QUINSIB-The Database on Quaternary Insects of North-Eastern Siberia (Preliminary version 2, 02. 06)

Virina E.I. 1997. Paleomagnetic stratigraphy of the Pliocene/Pleistocene sediments of the Kolyma Lowland and some problems of correlation with sites in Alaska and the Yukon // M.E. Edwards, A.V. Sher, R.D. Guthrie (eds.). Terrestrial paleoenvironmental studies in Beringia. Fairbanks: University of Alaska Museum. P.19-24.

Wickham H.F. 1917. Some fossil beetles from the Sangamon peat, Champaign Co., Ill. // American Journal of Science (4th Ser.). Vol.44. P.137-145.

Wickham H.F. 1919. Fossil beetles from Vero, Florida // American Journal of Science (4th Ser.). Vol.47. P.355357.

Williams N.E., Westgate J.A., Williams D.D., Morgan A., Morgan A.V. 1981. Invertebrate fossils (Insecta: Trichoptera, Diptera, Coleoptera) from the Pleistocene Scarborough Formation at Toronto, Ontario, and their paleoenvironmental significance // Quaternary Research. Vol.16. P.146-166.

Responsible editor A.A. Kotov 